\title{
THE CRIME OF UNCONSTITUTIONAL CHANGE OF GOVERNMENT AND POPULAR UPRAISINGS IN AFRICA: ISSUES AND CHALLENGES
}

\author{
(2020) 28(3) African Journal of International and Comparative Law 432-465 \\ https://www.euppublishing.com/loi/ajicl \\ MANISULI SSENYONJO \\ manisuli.ssenyonjo@brunel.ac.uk
}

\begin{abstract}
Several African States have experienced military coups as a form of government change, undermining constitutional change of governments, human rights and threatening regional peace and security in Africa. This article examines the crime of unconstitutional change of government in Africa. It considers the jurisdiction of the International Criminal Court (ICC) and the International Criminal Law section of the African Court of Justice and Human and Peoples' Rights over the crime of unconstitutional change of government. It then examines the scope of the crime of unconstitutional change of government and whether there is a right to peaceful rebellion against undemocratic governments in Africa. It also considers the impact of immunity granted to African Heads of States on the prosecution of the crime of unconstitutional change of government. It further explores whether the imposition of the death penalty by some domestic courts for the crime of unconstitutional change of government is compatible with African States' international human rights obligations under the African Charter on Human and Peoples' Rights and other human rights instruments. This is followed by a consideration of the challenge of providing funds for the benefit of victims of crimes including unconstitutional changes of government.
\end{abstract}

\section{Keywords}

Unconstitutional Change of Government; popular upraisings; African Court of Justice and Human and Peoples' Rights; peaceful rebellion; civil and political rights; immunity; death penalty; right to life 